\title{
Physical Parameters of Used Cooking Oil Clearance Quality Based on Active Charcoal Temperature
}

\author{
Dewi Oktofa Rachmawati ${ }^{1, *}$ Iwan Suswandi ${ }^{1}$
}

\author{
${ }^{1}$ Physic Education Study Program, Universitas Pendidikan Ganesha, Singaraja, Indonesia \\ *Corresponding author.Email: dewioktofa.r@undiksha.ac.id
}

\begin{abstract}
Oil purification is a common method used by the community to reuse used cooking oil. The use of various adsorbents that are rampantly carried out aimed at obtaining the quality of used cooking oil that is safe for consumption. However, in the adsorption process, not all adsorbents can restore the quality of cooking oil. Active charcoal is one of the effective adsorbents used for the purification process. Heating active charcoal is carried out to activate the adsorbent in order to increase the adsorption capacity of the contaminants and water content in the oil. Physical parameter of used cooking oil purification quality based on active charcoal temperature was decribed in this study. Clarified used cooking oil was cooking oil with 3 times of discontinuous use. The temperature of the active charcoal adsorbent varied, namely $27 \mathrm{oC}, 40 \mathrm{oC}, 50 \mathrm{oC}, 70 \mathrm{oC}$, and $90 \mathrm{oC}$. The color test was carried out organoleptically and analyzed using the senses of the eye. Density test used the principle of mass to volume ratio. The oven method with the principle of losing weight at 1050C was used to test the moisture content. The refraction index test used the principle of parallel plan glass refraction. All data were analyzed descriptively referring to the quality standard of cooking oil, namely SNI number: 3741 of 2013. Used cooking oil purified with active charcoal adsorbent at a temperature of $90 \mathrm{o} \mathrm{C}$ has a golden yellow color with oil density value of $0.8763 \pm 0.0336 \mathrm{gram} / \mathrm{cm} 3$, the refraction index of the oil $1.447 \pm 0.029$, water content in oil $0.087 \pm 0.171 \%$.
\end{abstract}

Keywords: Active charcoal, Physical parameters, Used cooking oil.

\section{INTRODUCTION}

Used cooking oil is oil produced from frying leftovers for more than one use. The reuse of used cooking oil is rife by the community lately. Used cooking oil that is safe to reuse must go through a purification process and meet cooking oil quality standards. The purification of used cooking oil in the community is generally carried out by precipitation and the use of adsorbents. Adsorbents such as rice, potato and charcoal are most dominantly used. People use the color change of cooking oil as an indicator that the oil is safe to reuse.

The damage to cooking oil is not only marked by changes in color, smell, taste, but also due to an increase in water content, peroxide number, free fatty acids and metal contamination. This damage is caused by the process of hydrolization, oxidation and polymerization which will produce an unpleasant taste, as well as damage to some vitamins and essential fatty acids contained in the oil. Oil containing water triggers a hydrolysis reaction. This reaction causes rancidity in the oil [1]. The use of cooking oil that has been contaminated or has damaged physico-chemical properties can cause long-term disease [2,3] because $5 \%-40 \%$ of cooking oil is left on food. which is obtained by frying.

The water content in the oil greatly affects the quality of the oil. The free fatty acid content and peroxide value in the oil are low, but if the water content is high, the hydrolysis rate is high. Fats are easily broken down into glycerol and free fatty acids which can be harmful to health. Oils with high water content tend to have a short shelf life [4]. In addition to water content, other physical parameters that determine the quality of cooking oil are color, density, and refraction index. Research by [5] shows that there are changes in the physical and chemical characteristics of the use of oil in the long term. 


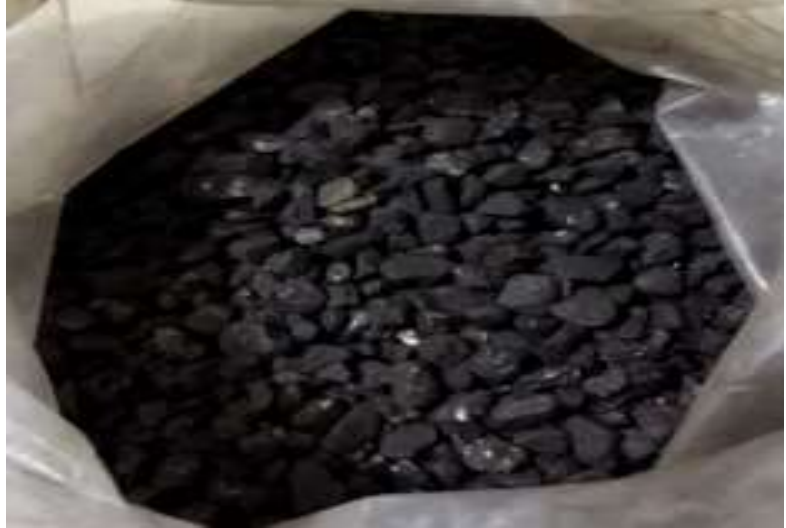

Figure 1 Coconut shell active charcoal

The purification of used cooking oil is carried out with the aim of removing unpleasant tastes and odors, undesirable colors in the oil, and extending the shelf life before being safely reused. The purification of used cooking oil with the use of adsorbent is a simple and efficient process [6]. The use of adsorbents in oil purification can reduce metal contamination, water content, organic and non-organic compounds that cannot be overcome only by precipitation. Active charcoal is active carbon that can adsorb anions, cations, and molecules in the form of organic and inorganic compounds in solution or gas. This active charcoal is black (can be seen in Figure 1), in the form of micro crystals, odorless, tasteless, hygroscopic, insoluble in water, bases, acids, organic solvents, and has a very large surface area and number of pores. The surface area of active charcoal ranges from 3000-3500 $\mathrm{m}^{2} /$ gram.

The adsorption power is influenced by the porosity of the active charcoal. Active charcoal with a large porosity has a higher adsorption capacity than active charcoal with a small porosity. The porosity of active charcoal can be increased by activating it physically or chemically. Physical activation can be done by heating. Heating causes the charcoal pores to open so that it can increase adsorption.

The use of active charcoal in the purification process is able to adsorb dyes up to $95-97 \%$ of the total dyes contained in the oil. Research by Yustinah [7] shows the use of active charcoal from coconut husks can reduce oil turbidity. G. Pari [8] in his research showed an increase in brightness of $2.04 \%$ in the color of used cooking oil that was purified using active charcoal from sawdust. In addition to adsorbing dyes, active charcoal can also absorb unwanted odor substances and reduce the water content in the oil. S.O. Mustafa [9] research shows that the amount of active charcoal used in the process of purifying used cooking oil has an effect on adsorption. The use of 5.5 grams of active charcoal in 50 grams of used cooking oil with an adsorption time of 80 minutes can increase adsorption up to $97.91 \%$.

In addition to changes in color and water content in the oil, active charcoal is used to reduce the refraction index and density values. Changes in physical parameters that can be observed in the cooking oil purification process reflect the physical parameters of the quality of used cooking oil.

Color is the result of the interpretation of the sense of sight (eyes) based on light reflected by objects. Density is used to characterize the mass of a fluid system. In fluids such as cooking oil, variations in pressure and temperature have an effect on the density value. A homogeneous fluid with mass, $m$ and volume, $V$, its density is calculated using the formula:

$\rho=\frac{m}{V}$

Moisture content indicates the amount of water content in a substance. The water content is expressed in $\%$ and calculated using the formula:

$K=\frac{m_{1}-m_{2}}{m_{1}} \times 100 \%$

Where $m_{1}$ is the weight of the substance and $m_{2}$ is the weight of the substance after heating. A high percentage of water content indicates a substance containing high amounts of water.

The refraction index is a measure of how far a medium can refract light. The absolute refraction index for light moving from one medium to another is expressed by the Snellius equation [10].

$n=\frac{\sin \theta_{i}}{\sin \theta_{r}}$

Where $\sin \theta_{\mathrm{i}}$ and $\sin \theta_{\mathrm{r}}$ are the sine of incidence angle and the sine of refraction angle. A medium with a higher index of refraction is a medium that refracts light more strongly.

The role of temperature on active charcoal activation by heating is very large. At a certain temperature, active charcoal becomes effective at adsorbing unwanted substances. However, heating at a temperature that is too high causes damage to active charcoal, so that the adsorption ability decreases. The temperature of active charcoal as an adsorbent in the purification process is interesting to study in relation to the quality of used cooking oil.

This study aimed at describing the physical parameters of the quality of cooking oil purification based on the temperature of the active charcoal adsorbent. The results of the study can educate the public that the purification of used cooking oil is safe to be re-consumed if it meets oil quality standards including physical-, chemical parameters. 


\section{METHOD}

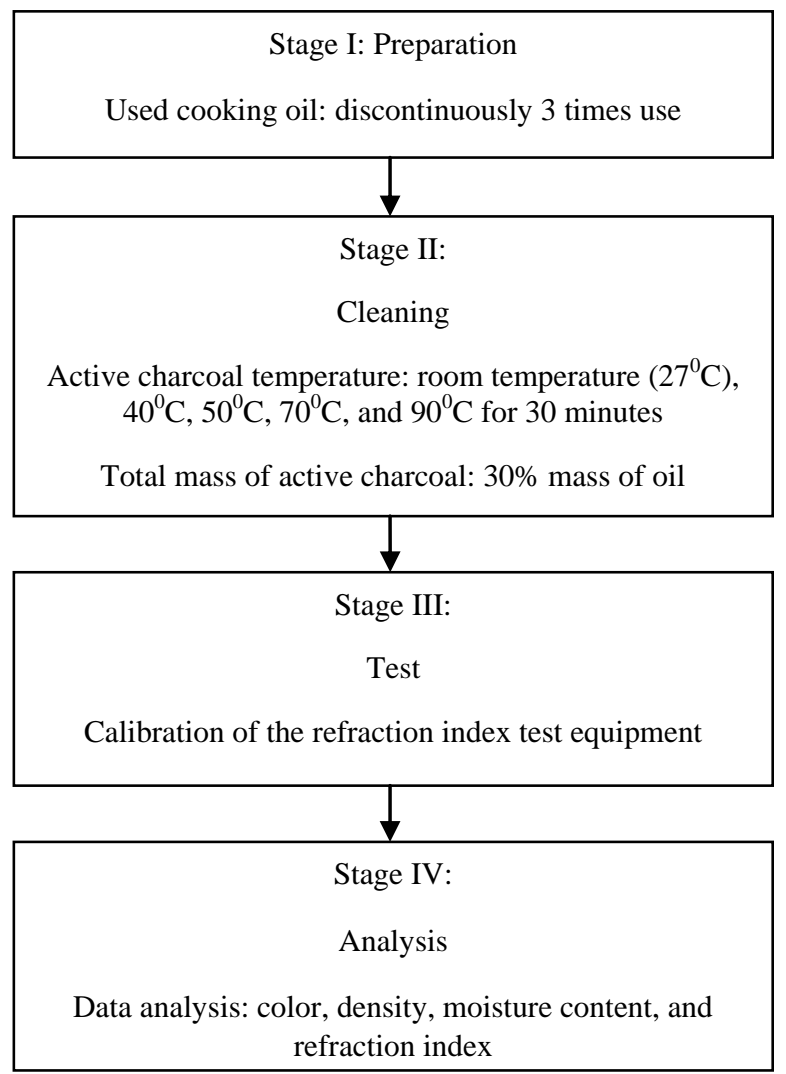

Figure 2 Research stages

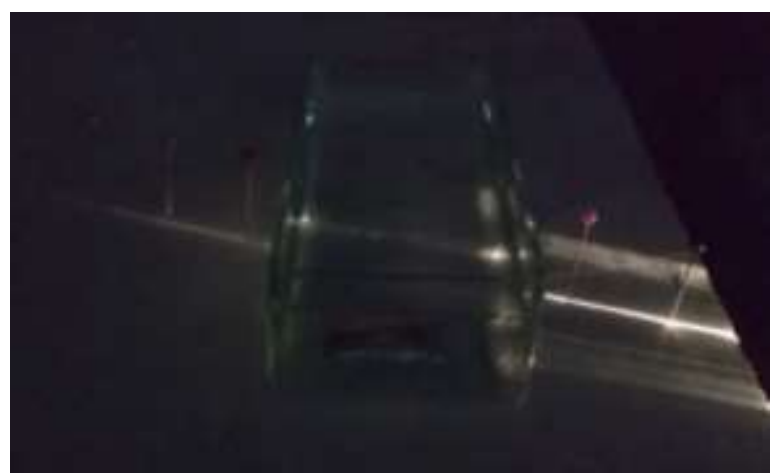

Figure 3 Calibration of the refraction index tool

The stages of implementing this research are presented in Figure 2.

The purified used cooking oil is cooking oil that is the result of discontinuously 3 times use. Active charcoal was heated for 30 minutes at $40^{\circ} \mathrm{C}, 50^{\circ} \mathrm{C}, 70^{\circ}$ $\mathrm{C}$, and $90^{\circ} \mathrm{C}$. Used cooking oil is allowed to stand for 24 hours before filtering. Testing the quality characteristics of used cooking oil was carried out after 2 times of filtering.

The physical parameters of the purification quality of cooking oil studied were color, moisture content density, and refraction index. The color test was carried out by the organoleptic method using the sense of sight (eyes). Color analysis was carried out by 3 panelists. The results of the analysis refer to the prerequisites for color quality standards based on SNI 3741 - 2013, namely clear without color. The principle of the ratio of mass to volume is used in the density test. Oil density is calculated using the formula in equation (1). The standard requirement for the quality of cooking oil density is $0.900 \mathrm{gr} / \mathrm{cm}^{3}$.

The oven method was chosen to test the water content in the oil. The oil was heated in an electric oven UN 160 at $105^{\circ} \mathrm{C}$ for 1 hour and cooled in a desiccator for 30 minutes. The heating was repeated until a constant weight was obtained. The loss at heating weight of $105^{\circ} \mathrm{C}$ is considered as the moisture content in the test sample. The water content is calculated using the formula in equation (2). Referring to the quality standard of cooking oil, the water content in the oil is required to be a maximum of $0.2 \%$.

The refraction index was tested by the plan parallel glass refraction method. Prior to the refraction index test, the test equipment was calibrated. Calibration of the test equipment using water and air media that have been known the refraction index values can be seen in Figure 3. As a light source, a ray-box was used. Glass with a thickness of $0.2 \mathrm{~cm}$ was used for oil containers. The refraction index value was obtained by measuring the angle of bending of light. The refraction index was calculated using the formula in equation (3). Required refraction index value is $1.448-1.450$.

The data were analyzed descriptively referring to the quality prerequisites for cooking oil based on SNI number 3741 of 1995.

\section{RESULTS AND DISCUSSION}

The results of the purification of used cooking oil with active charcoal at a temperature of 27 o C -90 o C to changes in oil color are listed in Table 1 . The purification of used cooking oil with active charcoal at $90^{\circ} \mathrm{C}$ has a significant color change compared to active charcoal at room temperature, $40^{\circ} \mathrm{C}, 50^{\circ} \mathrm{C}$, and $70^{\circ} \mathrm{C}$. Heating at a temperature of $90^{\circ} \mathrm{C}$ makes the area and volume of active charcoal pores the largest. In addition, the heating produces a difference in potential energy on the surface of the active charcoal and dye as adsorbate. The surface attraction of active charcoal against the adsorbate increases at this temperature. The adsorption of dyes by the surface of the active charcoal pores is maximized. This is indicated by a change in the color of the used cooking oil. The color of the used cooking oil changes from brownish yellow to golden yellow, as shown in the picture in Table 1. 
Table 1. Changes in the color of used cooking oil

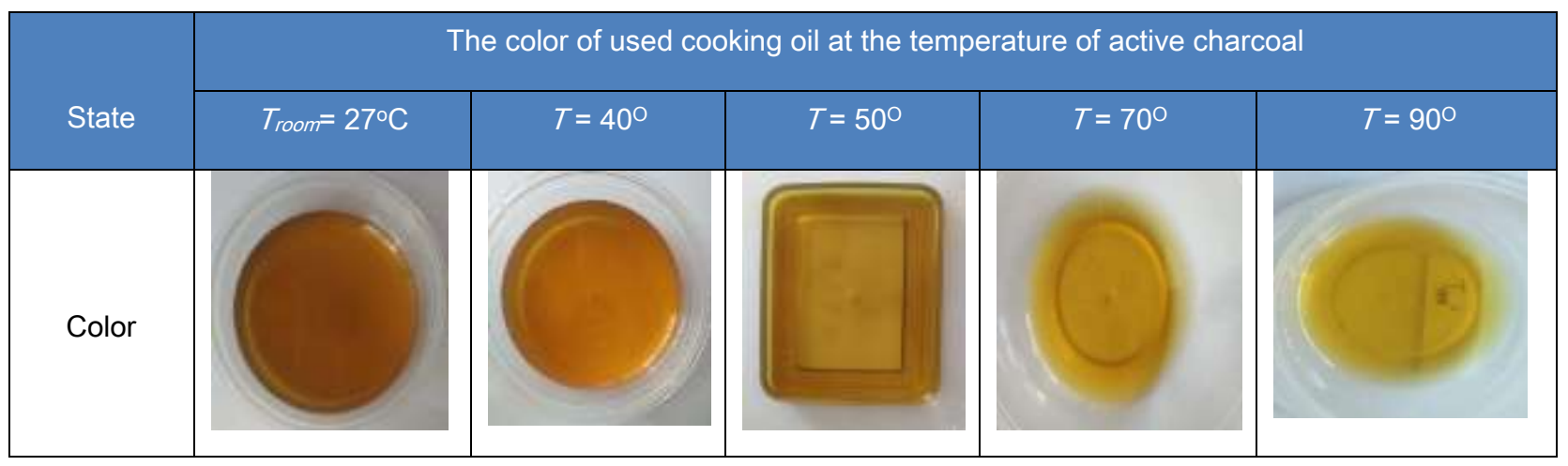

Table 2. Density of used cooking oil

\begin{tabular}{|c|r|r|r|r|r|}
\hline \multirow{2}{*}{ Used cooking oil } & \multicolumn{5}{|c|}{ Density at temperature active charcoal $\left(\mathrm{gr} / \mathrm{cm}^{3}\right)$} \\
\cline { 2 - 6 } & \multicolumn{1}{|c|}{$T_{\text {room }}=27^{\circ} \mathrm{C}$} & $T=40^{\circ}$ & $T=50^{\circ}$ & $T=70^{\circ}$ & $T=90^{\circ}$ \\
\hline Sample of test 1 & 0.8831 & 0.8829 & 0.8812 & 0.8795 & 0.8762 \\
\hline Sample of test 2 & 0.8832 & 0.8831 & 0.8813 & 0.8792 & 0.8763 \\
\hline Sample of test 3 & 0.8832 & 0.8831 & 0.8811 & 0.8793 & 0.8763 \\
\hline Density & $0.8832 \pm 0.0339$ & $0.8830 \pm 0.0314$ & $0.8812 \pm 0.0258$ & $0.8793 \pm 0.0207$ & $0.8763 \pm 0.0336$ \\
\hline
\end{tabular}

The absorption of active charcoal against dyes increased with an increase in the temperature of the active charcoal. Research by [11] and [12] showed that the purification with active charcoal of Leucaena Leucocephala wood was very effective in changing the color of used cooking oil. The golden yellow color of the used cooking oil that was purified with active charcoal at a temperature of $90^{\circ} \mathrm{C}$ met the prerequisites for cooking oil quality standards based on SNI: 37412013.

The dissolving of ingredients that were fried in oil could increase the density of used cooking oil. Heating active charcoal at a temperature of $90^{\circ} \mathrm{C}$ made the active charcoal surface able to attract more strongly dissolved substances in oil or contaminants. The tensile force that held the contaminants in the oil solution was smaller than the surface tension of active charcoal. Contaminants entered the pores of the active charcoal and accumulated in it more. So that the mass of oil at a temperature of $90^{\circ} \mathrm{C}$ active charcoal was small, the density of used cooking oil became small. The density of used cooking oil that was purified with active charcoal adsorbent at $90^{\circ} \mathrm{C}$ temperature was $0.8763 \pm 0.0336 \mathrm{gram} / \mathrm{cm}^{3}$. The decrease in density was $0.0069 \mathrm{gram} / \mathrm{cm}^{3}$ from the density resulting from the purification with active charcoal adsorbent at room temperature. The density of used cooking oil as a result of purification with active charcoal decreases with an increase in the temperature of active charcoal. The density value of used cooking oil and the temperature of the active charcoal adsorbent are listed in Table 2.
The specific gravity of soybean cooking oil resulted from the refining process had decree [13]. The density value obtained from the results of this study was smaller than the standard prerequisite value for cooking oil quality, which was $0.900 \mathrm{gr} / \mathrm{cm}^{3}$. The difference in the mass of used cooking oil before and after heating on the three test samples is shown in Figure 4.

Active charcoal is insoluble in water, alkaline, and hygroscopic. Heating active charcoal caused the charcoal to dehydrate water molecules. In this condition, the pores of active charcoal adsorbed more water molecules. The largest adsorption of water molecules occurred at the active charcoal with a temperature of $90^{\circ} \mathrm{C}$

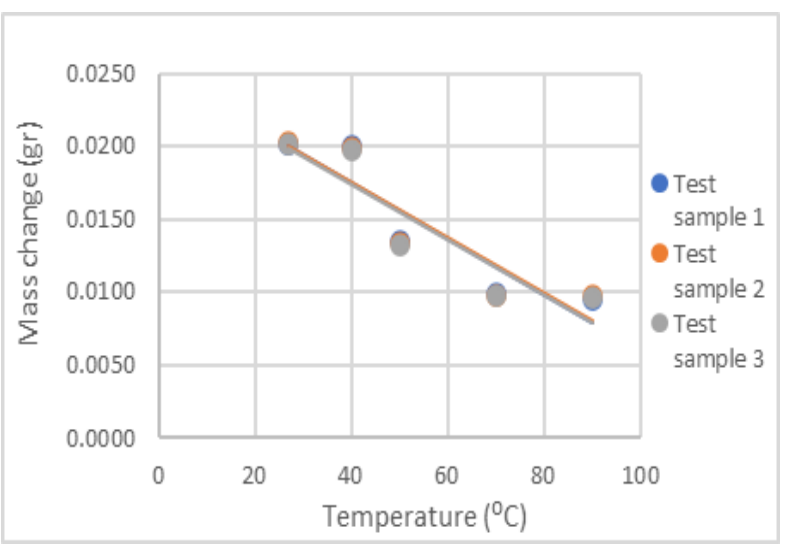

Figure 4 The difference in the mass of used cooking oil 
Table 3. Moisture content in used cooking oil

\begin{tabular}{|l|c|c|c|c|c|}
\hline \multirow{2}{*}{ Used cooking oil } & \multicolumn{5}{|c|}{ Moisture Content (\%) at active charcoal temperature } \\
\cline { 2 - 6 } & $T_{\text {room }}=27^{\circ} \mathrm{C}$ & $T=40^{\circ}$ & $T=50^{\circ}$ & $T=70^{\circ}$ & $T=90^{\circ}$ \\
\hline Sample of test 1 & 0.196 & 0.139 & 0.107 & 0.094 & 0.089 \\
\hline Sample of test 2 & 0.197 & 0.138 & 0.110 & 0.091 & 0.086 \\
\hline Sample of test 3 & 0.196 & 0.138 & 0.109 & 0.091 & 0.086 \\
\hline Moisture content & $0.196 \pm 0.101$ & $0.138 \pm 0.083$ & $0.109 \pm 0.092$ & $0.092 \pm 0.139$ & $0.087 \pm 0.171$ \\
\hline
\end{tabular}

Table 4. Refraction index of used cooking oil

\begin{tabular}{|c|r|r|r|r|r|}
\hline \multirow{2}{*}{ Angle $\theta_{i}$} & \multicolumn{5}{|c|}{ Refraction index at active charcoal temperature } \\
\cline { 2 - 6 } & \multicolumn{1}{|c|}{$T_{\text {room }}=27^{\circ} \mathrm{C}$} & \multicolumn{1}{c|}{$T=40^{\circ}$} & \multicolumn{1}{c|}{$T=50^{\circ}$} & $T=70^{\circ}$ & \multicolumn{1}{c|}{$T=90^{\circ}$} \\
\hline $20^{\circ}$ & 1.414 & 1.465 & 1.414 & 1.454 & 1.414 \\
\hline $40^{\circ}$ & 1.612 & 1.496 & 1.461 & 1.459 & 1.466 \\
\hline $60^{\circ}$ & 1.509 & 1.510 & 1.529 & 1.456 & 1.461 \\
\hline Refraction index & $1.512 \pm 0.099$ & $1.490 \pm 0.022$ & $1.468 \pm 0.058$ & $1.456 \pm 0.003$ & $1.447 \pm 0.029$ \\
\hline
\end{tabular}

After repeated heating at a temperature of $105^{\circ} \mathrm{C}$ for 1 hour and cooling in a desiccator for 30 minutes 3 times, a constant mass difference was obtained. The smallest mass reduction in test sample 1 was 0.0096 gr. The mass reduction of the three test samples at a certain temperature did not differ much. The mass reduction was proportional to the water content in the oil. The smaller the mass reduction, the lower the moisture content in the oil and vice versa.

The water content in the oil and the temperature of the active charcoal adsorbent are presented in Table 3. The use of active charcoal adsorbent at room temperature for purification resulted in a water content of $0.2 \%$, namely $0.196 \pm 0.101 \%$. This value was still higher than the water content in the used cooking oil which was purified with active charcoal as an adsorbent at a temperature of $90^{\circ} \mathrm{C}$. The decrease in water content reached $0.109 \%$ from the initial state. Active charcoal at a temperature of $90^{\circ} \mathrm{C}$ was more effective at adsorbing water molecules than active charcoal at other temperatures. The water content in the used cooking oil decreased with the increase in the temperature of the active charcoal adsorbent. The use of active charcoal at room temperature, $40^{\circ} \mathrm{C}, 50^{\circ} \mathrm{C}, 70^{\circ} \mathrm{C}$, and $90^{\circ} \mathrm{C}$ in the purification of used cooking oil produced water content that met the prerequisites for cooking oil quality.

The water content in used cooking oil determined the quality of the cooking oil. The water content could trigger the hydrolysis reaction which produced glycerol and free fatty acids. The higher the water content in the oil, the higher the free fatty acids formed from this hydrolysis reaction. Research by S.O. Mustafa [9] showed that the water content of used cooking oil that was purified with active charcoal from ironwood sawdust (Eusideroxylonzwageri) reached $0.0559 \%$.

The refraction index of used cooking oil that was purified with active charcoal adsorbent at temperatures of $27^{\circ} \mathrm{C}, 40^{\circ} \mathrm{C}, 50^{\circ} \mathrm{C}, 70^{\circ} \mathrm{C}$, and $90^{\circ} \mathrm{C}$ was in the value interval of $1.447 \pm 0.029-1.512 \pm 0.099$, as shown in table 4 . The results of the purification of used cooking oil with active charcoal as an adsorbent at a temperature of $90^{\circ} \mathrm{C}$ showed that this oil was able to refract light with a refraction angle of $13.8^{\circ}-37.5^{\circ}$ at an angle of incidence of $20^{\circ}-60^{\circ}$. This refraction index value was the smallest compared to the refraction index of used cooking oil purification with active charcoal at temperatures of $27^{\circ} \mathrm{C}, 40^{\circ} \mathrm{C}, 50^{\circ} \mathrm{C}$, and $70^{\circ} \mathrm{C}$. This showed that used cooking oil bent light with a small bending angle. The refraction index of the oil decreased with increasing temperature of the active charcoal adsorbent.

The refraction index of used cooking oil as a result of purification with active charcoal at room temperature was $1.512 \pm 0.099$. The large bending of light in this medium indicated a small angle of refraction of light. Figure 5 shows the relationship between the refraction index and the optical density of used cooking oil.

Used cooking oil that was purified with active charcoal at a temperature of $90^{\circ} \mathrm{C}$ which has the highest optical density was able to bend the direction of light the most towards the normal line. On the other hand, 
used cooking oil with low optical density bent the smallest light direction away from the normal line.

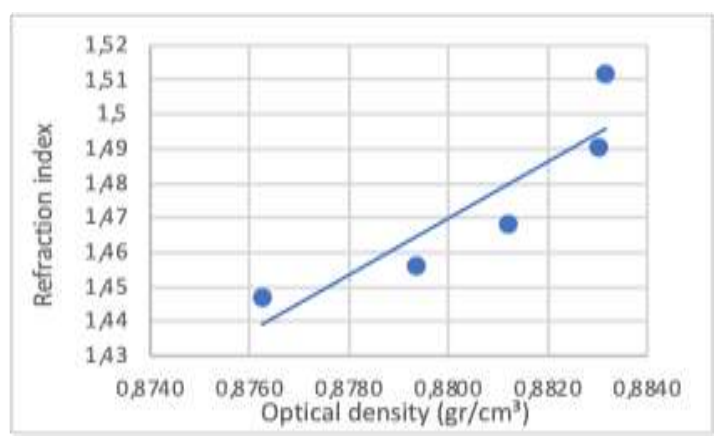

Figure 5 Graph of the relationship between the refraction index and the density of used cooking oil.

The graph in figure 5 shows the greater the optical density of a material, the greater its refraction index. And the greater the optical density, the greater the bending direction of light passing through the medium. In other words, light is refracted at an angle of refraction close to the normal in a dense optical medium. On the other hand, light is refracted away from the normal when it passes through a less dense optical medium [10]. The magnitude of the bend or shift in the direction of light propagation out of a medium depends on the optical density of the medium. This optical density is the property of a translucent medium in passing light. The optical density of a medium is expressed in terms of the refraction index.

The damage of cooking oil due to heating resulted in an increase in the refraction index [5]. Research by A.A.E-R. Mohdaly [13] and T. Ariani [14] showed a decrease in the refraction index after the cooking oil refining process. The refraction index of used cooking oil purified with active charcoal adsorbent at temperatures of $27^{\circ} \mathrm{C}, 40^{\circ} \mathrm{C}, 50^{\circ} \mathrm{C}, 70^{\circ} \mathrm{C}$, and $90^{\circ} \mathrm{C}$ was less than the quality prerequisite for cooking oil based on SNI 3741-2013, which was 1.448-1.450.

\section{CONCLUSION}

The purification of used cooking oil with active charcoal as an adsorbent at temperatures of $40^{\circ} \mathrm{C}, 50^{\circ} \mathrm{C}$, $70^{\circ} \mathrm{C}$, and $90^{\circ} \mathrm{C}$ can change the color of the oil and can reduce the value of density, moisture content and refraction index. The optical density of used cooking oil is in the value interval of $0.8783 \pm 0.0336$ $0.8832 \pm 0.0336 \mathrm{gr} / \mathrm{cm}^{3}$. The physical parameters of the quality of used cooking oil purification with active charcoal as adsorbent at temperatures of $27^{\circ} \mathrm{C}, 40^{\circ} \mathrm{C}$, $50^{\circ} \mathrm{C}, 70^{\circ} \mathrm{C}$, and $90^{\circ} \mathrm{C}$ that meet the quality prerequisites for cooking oil based on SNI 3741-2013 are color and water content. In order for the purified used cooking oil to be used safely, it must meet the physical-chemical test requirements.

\section{ACKNOWLEDGMENT}

Thank you to LPPM Ganesha University of Education, the basic physics laboratory of the S1 Physics Education study program, for the funds and facilities provided for this research.

\section{REFERENCES}

[1] S. Ketaren, Pengantar Teknologi Minyak dan Lemak Pangan. Jakarta: UI Press, 1986.

[2] R. K. Deshmukh, "The effect of repeatedly cooking oils on health and wealth of a country: a short communication," J. Food Process. Technol., pp. 14, 2019, doi: http://dx.doi.org/10.35248/21577110.19.10.807.

[3] X. F. Leong, C. Y. Ng, K. Jaarin, and M. R. Mustafa, "Effects of repeated heating of cooking oils on antioxidant content and endothelial function," Austin J. Pharmacol. Ther., vol. 3, no. 2, pp. 1-7, 2015.

[4] S. Sudarmadji, B. Haryono, and Suhardi, Analisa Bahan Makanan dan Pertanian. Yogyakarta: Liberty, 1989.

[5] M. Taufik and H. Seftiono, "Karakteristik fisik dan kimia minyak goreng sawit hasil proses penggorengan dengan metode deep-fat fraying," J. Teknol. Univ. Muhammadiyah Jakarta, vol. 10, no. 2 , pp. 123-130, 2018, doi: https://dx.doi.org/10.24853/jurtek.10.2.123-130.

[6] M. Maskan, "The recovery of used sunflower seed oil utilizedin repeated deep-fat frying process," Eur Food Res Technol, pp. 26-31, 2003, doi: http://dx.doi.org /10.1007/s00217-003-0794-0.

[7] H. Yustinah, "Adsorbsi minyak goreng bekas menggunakan arang aktif dari sabut kelapa," in Prosiding Seminar Nasional Teknik Kimia "Kejuangan," 2011, pp. 1-5.

[8] G. Pari, D. Tohir, and J. F. Mahpudin, "Activated charcoal from wood sawdust as adsorbent material for frying oil refinery,” J. Penelit. Has. Hutan, vol. 24, no. 4, pp. 309-322, 2006.

[9] S. O. Mustafa, A. Kurniawan, and N. A. Muslimin, "Pemurnian minyak jelantah dengan metode adsorbsi menggunakan arang aktif dari serbuk gergaji kayu ulin (Eusideroxylon zwageri)," J. Ris. Teknol. Ind., pp. 124-132, 2021, doi: https://dx.doi.org/10.26578/jrti.v14i2.6067.

[10] H. D. Young and R. A. Freedman, Fisika Universitas. Jakarta: Erlangga, 2003.

[11] F. C. Hidayati, Masturi, and I. Yulianti, "Pemurnian minyak goreng bekas pakai (jelantah) 
dengan menggunakan arang bonggol jagung," J. Ilmu Pendidik. Fis., vol. 1, no. 2, pp. 67-70, 2016.

[12] H. N. Muhammad, F. Nikmah, N. U. Hidayah, and A. K. Haqiqi, "Arang aktif kayu leucaena leucocephala sebagai adsorben minyak goreng bekas pakai (minyak jelantah)," Phys. Educ. Res. J., vol. 2, no. 2, pp. 123-130, 2020, doi: https://dx.doi.org/10.21580/perj.2020.2.2.6176.

[13] A. A. E.-R. Mohdaly, K. A. E.-H. Seliem, A. E.-M. Maher, and A. A. T. Mahmoud, "Effect of refining process on the quality characteristics of soybean and cotton seed oils," Int. J. Curr. Microbiol.
Applied. Sci., vol. 6, no. 1, pp. 207-222, 2017, doi: http://dx.doi.org/10.20546/ijcmas.2017.601.026.

[14] T. Ariani and O. P. U. Gumay, "Pengaruh adsorben terhadap kualitas fisik minyak," Sci. Phys. Educ. J., vol. 1, no. 1, pp. 1-6, 2017. 